Heritage attractions, competitive pressures and adaptation: The case of the British seaside pier

\author{
Anya Chapman \\ Bournemouth University Business School \\ Bournemouth University \\ Fern Barrow \\ Poole \\ Dorset, UK \\ BH12 5BB \\ achapman@bournemouth.ac.uk
}

\title{
Duncan Light
}

Bournemouth University Business School

Bournemouth University

Fern Barrow

Poole

Dorset, UK

$\mathrm{BH} 12$ 5BB

\section{Steven Richards}

Bournemouth University Business School

Bournemouth University

Fern Barrow

Poole

Dorset, UK

$\mathrm{BH} 12$ 5BB

Word count: 7,441 (including tables, abstract, references \& key words) 


\title{
Heritage attractions, competitive pressures and adaptation: The case of the British seaside pier
}

\begin{abstract}
Heritage visitor attractions operate in a dynamic environment requiring them to adapt and respond to changing circumstances which they cannot control. This paper focuses on adaptation strategies adopted by one type of heritage resource: the seaside pier in the UK. As part of the heritage of mass tourism itself piers were created in a specific context and as that context has changed, they have needed to adapt to remain viable and competitive as attractions. A combination of observational field visits to all UK piers and in-depth interviews with selected pier owners was used to examine strategies of adaptation. Three pier categories were identified, characterised by different adaptation strategies and the experiences offered to visitors. The Family Entertainment pier has adopted a strategy of consolidation, offering a traditional product with some diversification to suit contemporary consumer tastes. The Twenty-first Century Innovator pier has followed a strategy of differentiation, focussed on providing contemporary entertainments and catering. The Heritage pier has differentiated by offering a nostalgic and uncommercialized experience of the traditional seaside holiday. These strategies enable individual piers to remain competitive as attractions but some have more robust business models and are in a stronger financial position to deal with ongoing and future challenges.
\end{abstract}

Keywords: seaside piers, adaptation strategies, competition, visitor experience, coastal tourism 


\section{Introduction}

Heritage attractions, like all visitor attractions, operate in a dynamic environment and must be prepared to respond and adapt to changes in this environment (Connell et al 2015; Leask 2016). Much of the literature on heritage attractions has focussed on one particular form of adaption: the conversion of heritage sites into tourism products (McKercher et al 2004), a practice known as 'adaptive reuse' (Bullen and Love 2011). This is a form of conservation practice which seeks a sustainable future for historic buildings and, for more than a century, a common reuse strategy for historic resources has been to reconfigure them as places for tourists to visit (Timothy and Boyd 2003).

However, heritage resources have to respond to changing circumstances in other ways. In particular the demand for heritage tourism can be highly volatile (Garrod and Fyall 2000). Consumer tastes can change substantially over time so that heritage resources which were once very popular can experience a fall in demand (Ashworth 2010). These changes are frequently linked to much broader developments within the external environment which heritage attractions are unable to control or influence. Therefore, all they can do is attempt to adapt to new circumstances in order to remain competitive as tourist sites. This issue is fundamental to contemporary heritage tourism but, with a few exceptions (Markwell, et al 1997; Chhabra 2007; Chapman and Light 2011; Darlow et al 2012) has received surprisingly little analysis.

This paper examines adaption to changing demand with reference to a specific type of heritage attraction: the seaside pier. This sector is of particular significance since piers are not a typical example of adaptive reuse. Instead, they were originally designed for tourism: they represent a part of the heritage of tourism itself. Seaside pleasure piers are commonplace in the United Kingdom (where 61 survive of which 56 are open to visitors) but are also present in other countries, including the Netherlands, France, Germany, Italy, the USA, Australia and China. Like other types of heritage attractions, piers have faced a situation of volatile and fragmented demand in recent decades. Similarly, they face particular constraints and challenges which limit their opportunities to adapt to new contexts. This paper analyses the strategies adopted by seaside piers in the UK to respond to broader changes in demand. In particular, it identifies three types of adaptation strategies that have enabled seaside piers to remain competitive and relevant in the twenty-first century. 


\section{Changing demand within the heritage attraction sector}

Visitor attractions exist within an extremely competitive and dynamic external environment (Richards and Wilkes 2008; Leask 2016; Weidenfeld et al 2016). Within the UK, attractions operate in a mature market, with sector growth averaging 2\% since 2015 (VisitBritain 2019a). Whilst demand has grown slowly, there has been an increase in supply within the sector, adding to competitive pressures faced (Bąkiewicz et al 2017). In the UK, the number of attractions has doubled since the 1980s (Stevens 2000). Not only do attractions face increased competition within the sector, they must also compete with other leisure activities such as the growth of in-home entertainment, the growth of the casual dining sector, and sport and live music events (Leask 2016).

The nature of demand has also become increasingly differentiated in recent years, as visitors search for new and unusual experiences. The attraction sector has responded by providing new types of attractions, offering themed experiences, DIY experiences such as escape rooms, and pop up attractions (Attractions Management 2016). Existing attractions have also responded to changing demand by enhancing the experience offered, for instance with the application of technology to provide interactive or immersive experiences. However, not all attractions are able to adapt and offer innovative new experiences, lacking the resources or expertise to do so (Weidenfeld et al 2016).

The heritage visitor attraction sector faces the same competitive pressures. Heritage attractions in the UK have underperformed the attractions sector as a whole, posting growth rates below the sector average over the last 30 years (VisitBritain 2019a). New forms of heritage are continually being developed and promoted for tourism (Timothy and Boyd 2006). Within the UK, f8bn has been invested in 44,000 UK heritage projects over the last 25 years (NLHF 2019). Such developments expand the choices available to tourists but also increase the pressure on existing heritage attractions in an increasingly congested heritage market (Garrod and Fyall 2000; Hughes and Carlsen 2010). Heritage attractions also face increasingly fragmented and differentiated demand (Jovicic 2014). Ashworth (2010: 285) argues that demand for heritage is "extremely prone to rapid shifts in fashion and changes in taste", in response to the changing needs and expectations of consumers.

This competitive wider environment presents particular challenges for heritage attractions that are dependent (to varying degrees) on revenue from visitors to fund conservation activity. Many heritage sectors have to contend with high expenditure (for example on conservation or maintenance) but generate relatively small revenues (Chan et al 2015). This is particularly the case in non-profit sectors 
(such as museums) which have historically been dependent on public funding but which have experienced a prolonged reduction in such funding in recent decades (Bąkiewicz et al 2017). However, some types of heritage attraction have limited potential to attract sufficient visitors to support the costs of conservation (Darlow et al 2012): such a situation may be particularly pronounced for heritage resources which were not originally intended to be used for tourism (see Ho and McKercher 2004). An additional constraint is that many heritage resources are protected by legislation in recognition of their historic value. However, this limits options when seeking to enhance or develop their product for heritage tourism consumption.

Furthermore, the managers of heritage resources may lack the desire, willingness or skills to respond and adapt to the competitive pressures of the heritage tourism market. This is especially the case in sectors with an established practice of non-commercial provision (Markwell et al 1997). The adaptive reuse of heritage sites requires a degree of commodification and commercial focus. However, managers may be reluctant to embrace market demand for tourism or product innovation, for fear of compromising or undermining the integrity or authenticity of their resource (Hughes and Carlsen 2010). This is commonplace at sites such as museums which have historically emphasised conservation, curatorship and education over tourism and commercial viability (Garrod and Fyall 2000). A further issue is limited technical knowledge or expertise pertaining to tourism among managers (Markwell et al 1997; Chhabra 2007; Darlow et al 2012). Thus, there may be a poor understanding of market demand and the expectations and requirements of visitors (Ho and McKercher 2004; Hughes and Carlsen 2010). In some cases, managers may be reluctant to acknowledge that they are in the business of heritage tourism altogether (Chhabra 2007; Bąkiewicz et al 2017; Chan et al 2015).

The issue of how heritage attractions adapt and respond to external changes and growing competitive pressure is under-explored in the heritage literature. There is a growing attention to the need for heritage resources to adapt to climate change and the prospect of rising sea levels (e.g. Hall et al 2016; Weber et al 2019). However, the ways in which different heritage sectors adapt to changing market conditions to remain competitive has been largely overlooked and the limited research which has addressed this issue has tended to focus on museums. This paper seeks to advance debate by focusing on how heritage attractions adapt to ensure their survival in a crowded marketplace. It does so with particular reference to seaside piers, a type of heritage resource which has, to date, received limited academic attention. 


\section{The heritage of seaside piers}

The history and development of British seaside resorts is well documented (Walton, 1992; Brodie 2018). In the eighteenth century coastal towns developed as spa resorts and later as places for sea bathing. At this time there were only two options for travelling to them: by horse-drawn carriage over land, or via the sea on boats. However, the latter presented a problem for visitors wanting to get ashore. Consequently, landing stages and jetties were built in order to accommodate passengers arriving by steamer (Wills and Phillips, 2014). These were plain structures, but as resorts became more established these structures were increasingly used by visitors for promenading. The first 'true' pleasure pier constructed at a British seaside resort opened in 1814, and was swiftly followed by several other 'promenading piers'. These charged a relatively high entrance fee, ensuring that piers at this time were used only by the social elite (Adamson, 1977).

By the 1850s railway networks had reached many British seaside resorts (Walton, 1992), resulting in resorts shifting from elite tourism to mass tourism. Piers changed from being transportation hubs to becoming venues for pleasure and entertainment. Consequently 85 pleasure piers were constructed between 1860 and 1905. These structures provided visitors, for a small fee, the highly novel experience of walking over the sea (Adamson, 1977; Brydon et al 2019). During the 1870s piers developed additional attractions and facilities for visitors, offering popular entertainments such as theatres, bandstands, pavilions, reading rooms, and kiosks. When Weston-Super-Mare's Grand Pier opened in 1904, it featured a 2000-seat theatre for shows including opera, music hall, and boxing. Seaside piers were extremely popular with visitors to the seaside but were also viewed as significant heritage resources by local communities (Brydon et al 2019).

After 1905 only five pleasure piers were constructed, and thereafter the number has progressively fallen. Some succumbed to storm damage, fire, or collisions with ships and were deemed too costly to replace. Furthermore, most established resorts had at least one seaside pier meaning that there was limited enthusiasm for constructing more. The outbreak of two world wars meant that the engineering skills and materials associated with piers were needed for the war effort. Indeed, during World War II many piers were sectioned (a section was cut out to stop enemy troops landing at the pier head), and although most were rebuilt after the war, some fell into disrepair and were later demolished. Between the outbreak of World War 1 and the end of the 1950s, 14 piers were destroyed or demolished. 
By the late 1960s and 1970s British seaside resorts faced increased competition from overseas package holidays and other UK destinations such as national parks and historic cities. British seaside resorts entered into a long period of decline as holiday destinations, and piers lost their importance. Piers were no longer viewed as fashionable attractions and, as maintenance costs increased, many were neglected. Some were demolished, others lay derelict, and some were destroyed by storms or fire. Indeed, the image of the decaying seaside pier became a metonym for the precarious state of coastal resorts more broadly. Since 1960, 15 seaside piers have been demolished or destroyed, leaving 61 (of which 56 are open to the public) in 2020 (Chapman et al 2020).

\section{Methodology}

This paper examines how seaside piers have adapted to remain competitive in response to changes in the external environment. A four-stage methodology was adopted. The first stage involved discussions with the National Piers Society to identify the key issues to examine in more detail. Based upon this expert input the following factors were identified: current status (open/closed); ownership and operation model (public, commercial, trust); recent developments; funding sources; protection status; events; and risks. The second and third stages of the methodology were concerned with the construction of a comprehensive database of the 56 piers in the UK open the public. The database included facilities for visitors; mode of presentation; physical conditions; recent investments; maintenance issues; recent development; and the competitive strengths and weaknesses of each pier. The second stage was desk-based research (undertaken by the first author) and took the form of a review of online newspaper articles about piers over the 2009-2019 period. This reportage was held in the archive of the National Piers Society. No formal analytical technique was used with these articles; instead the reportage was used to inform the database.

In the third stage, the desk research was supplemented through field-based observation and survey. Such observational data can be valuable in itself but can also complement that gained through other methods (Kearns 2005). All 56 piers were visited by the first and second authors. Data were recorded for the facilities and attractions currently offered to visitors, and the location of the pier within the wider resort. This form of data collection is similar to that of the 'mystery shopper' (Miller et al 2005). During each visit a subjective assessment was also made of the current physical condition of each pier, based on observation of the substructure (and informed by the first author's extensive experience of 
visiting piers over a 30 year period). Again, the data collected were used to inform and expand the piers database.

The fourth stage involved in-depth interviews with a selection of pier operators. Such expert interviews (Flick 2018) were intended to provide a detailed insight into the strategies of adaptation adopted by piers. A purposive sample was used to identify piers representing both different ownership models (commercial, public and third/charitable sector) and a range of approaches to development and securing funding. Five interviews were undertaken with the managers of piers in private/commercial sector ownership; 3 with managers of piers in public (local authority) ownership; and 2 with trustees of piers in charitable ownership. The proportion of interviews in each category closely mirrors the broader ownership of piers. The interviews (which ranged in length from one to two hours) were undertaken between March and May 2019. The interviewees all spoke in an official capacity (see Table 1) and gave permission to be quoted. Ten interviews were conducted by the first author, and it was clear that this number was sufficient to achieve data saturation (Bryman 2016). The interviews were analysed using a 'theoretical' or top-down form of thematic analysis (Braun and Clarke 2006) which was guided by searching for particular issues in the data.

Table 1: Details of Pier Interviews

\begin{tabular}{|l|l|l|}
\hline Ownership & Pier & Interviewee Role \\
\hline Commercial sector & & \\
\cline { 2 - 3 } & Brighton Palace & Chief Executive Officer (owner) \\
\cline { 2 - 3 } & Mumbles & Managing Director (owner) \\
\cline { 2 - 3 } & Clacton & Managing Director (owner) \\
\cline { 2 - 3 } & Felixstowe & Managing Director (owner) \\
\cline { 2 - 3 } & Skegness & Administration Manager (owner) \\
\hline \multirow{5}{*}{ Public sector } & & Council Deputy Leader (owner) \\
\cline { 2 - 3 } & Southend & Council Corporate Director (owner) \\
\cline { 2 - 3 } & Cromer & Executive Director (operator) \\
\cline { 2 - 3 } & Bournemouth & \\
\hline \multirow{5}{*}{ Third sector } & & Trust Chairperson (operator) \\
\cline { 2 - 3 } & Herne Bay & Trust Chief Executive (owner) \\
\cline { 2 - 3 } & Swanage & but leased to private opator \\
\hline
\end{tabular}

Note: Bournemouth Pier is public sector owned, but leased to private operator

As a result of the analysis of the database and the interview data, a categorisation of piers was developed, following the approach of Kluge (2002) for developing empirically grounded types. Three categories of pier were identified, based on their strategies of adaptation to the changing external environment. These categories were labelled as follows: 1) The Family Entertainment pier (25 
examples); 2) the Twenty-first Century Innovator pier (12 examples); and 3) the Heritage pier (19 examples). The distribution of piers within each category is shown in Table 2.

Table 2. Pier categories

\begin{tabular}{|c|c|c|}
\hline Family Entertainment Piers & $\begin{array}{l}\text { Twenty-first Century } \\
\text { Innovator Piers }\end{array}$ & Heritage Piers \\
\hline $\begin{array}{l}\text { Blackpool Central } \\
\text { Blackpool South } \\
\text { Bognor Regis } \\
\text { Brighton Palace } \\
\text { Burnham-on-Sea } \\
\text { Deal } \\
\text { Eastbourne } \\
\text { Great Yarmouth Wellington } \\
\text { Hastings } \\
\text { Llandudno } \\
\text { Lowestoft Claremont } \\
\text { Lowestoft South } \\
\text { Mumbles } \\
\text { Paignton } \\
\text { Ryde } \\
\text { Sandown } \\
\text { Southend-on-Sea } \\
\text { Southport } \\
\text { Southsea Clarence } \\
\text { Southsea South Parade } \\
\text { St. Annes } \\
\text { Teignmouth } \\
\text { Walton-on-the-Naze } \\
\text { Weymouth Bandstand } \\
\text { Weymouth Pleasure }\end{array}$ & $\begin{array}{l}\text { Aberystwyth } \\
\text { Boscombe } \\
\text { Bournemouth } \\
\text { Clacton } \\
\text { Cleethorpes } \\
\text { Felixstowe } \\
\text { Folkestone } \\
\text { Herne Bay } \\
\text { Penarth } \\
\text { Skegness } \\
\text { Southwold } \\
\text { Weston-S-M Grand }\end{array}$ & $\begin{array}{l}\text { Bangor } \\
\text { Beaumaris } \\
\text { Blackpool North } \\
\text { Clevedon } \\
\text { Cromer } \\
\text { Dunoon } \\
\text { Falmouth } \\
\text { Fort William } \\
\text { Gravesend Town } \\
\text { Great Yarmouth Britannia } \\
\text { Harwich } \\
\text { Hythe } \\
\text { Rothesay } \\
\text { Saltburn } \\
\text { Sunderland } \\
\text { Swanage } \\
\text { Torquay } \\
\text { Worthing } \\
\text { Yarmouth }\end{array}$ \\
\hline
\end{tabular}

Piers in bold are those interviewed as part of this study (see Table 1).

Adaptation strategies among seaside piers

\section{Family Entertainment piers}

Family Entertainment piers are predominantly found in larger seaside resorts (defined as those towns with a permanent population above 10,000 people (see Beatty et al 2011)). These piers have been able to survive with a similar product/market mix, benefiting from their location in established seaside resorts which retain significant visitor economies, attracting large numbers of visitors: the most successful pier in the UK (Brighton Palace Pier) attracts almost five million visitors a year (VisitBritain 
2019b). $44 \%$ of these piers enjoy legal protection (known as 'listed buildings' status), mostly at the lowest level of protection.

Piers in this category are predominantly $(80 \%)$ in commercial sector ownership. Most do not charge an entrance fee and are therefore dependent on revenue generated from attractions and facilities. Demand is highly seasonal and many piers in this category reduce their opening hours (or close entirely) during the winter. To maximise revenue during peak periods, almost every part of the deck space is used for attractions and facilities. One owner stated "you've got to be as commercial as you possibly can be" (Brighton). With the exception of Brighton Palace Pier, all the commercially owned Family Entertainment piers can be classed as small and medium-sized enterprises (SMEs), with the majority being family owned and operated for several generations. SME organisations can have limited financial resources and lack organisational slack (McGuinness and Johnson 2014), but can also have amassed a range of skills, knowledge and experience through path dependency (Helfat et al 2007).

These piers have adopted a strategy of consolidation in terms of product offered and markets served (Tribe 2016). They typically offer a variety of traditional products and services for the family market, such as funfairs, amusement arcades, bowling alleys, roller-skating, fast food, and bars with family or evening entertainment. Their target market is families with children who account for $41 \%$ of the market for coastal tourism in the UK (NCTA 2016). However, they are also used by local communities for events, fishing and other out-of-season activities.

Whilst Family Entertainment piers have followed a consolidation path, there is also some evidence of product innovation, driven by the competitive environment. One owner argued: "You've got to move with the times to always try different things" (Mumbles). In this context, some piers have invested in upgrading their entertainments. The manager of Brighton Palace Pier summarised her approach:

\footnotetext{
"You've just got to keep trying, introduce new products...we add things in, like in the arcade in particular, there's new games, there's virtual reality, there's augmented reality, all that sort of thing. We have all the new stuff. We will buy at some point new family rides".
} 
Other product developments have focussed on reducing seasonality, a key issue for all attractions (Goulding 2008). Developing products for local residents is one such approach (Connell et al 2015). This was exemplified by the owner of Southend Pier:

"I think one of the big things that we have done is trying to...extend the season...you can go and see Santa, there are ghost trains for Halloween so we can go and scare all the kids ... those sort of things that actually attract more people to go down the pier".

A recent adaption has been a focus on catering and dining. Traditionally, this was a secondary revenue stream for piers. However, many piers adapted their product offering to meet changing needs:

“Catering in my day was almost a bit of a necessary evil. You know, you've got to have somewhere for somebody to have a cup of tea. But... now a major contribution to the site is through the catering" (Mumbles).

For this owner, catering now accounted for around $50 \%$ of total revenue. A key to success was a diverse food and beverage offer, with increasing opportunities for high-end settings or experiences. One manager noted that, whilst there was a continuing demand for the traditional fast-food offering, visitors also valued more unusual dining experiences: "do people want to sit in a restaurant, drink a cocktail and look out at the sea? They do!" (Brighton)

Some piers had gone further, adapting both the product and market mix to diversify the visitor experience. Examples include sports bars and nightclubs intended for local students. This is illustrated by Southend Pier, where "we have a number of little beach huts at the end of the pier ... to allow micro business start-ups... you can now have a beer at the end of the pier".

For commercial sector pier owners in this category a priority is raising revenue to cover ongoing maintenance and insurance costs on piers, as illustrated at Brighton Palace Pier:

"We spend an enormous amount of money on it. We spend the best part of $£ 2$ million a year on maintenance, that's above and below the deck. If you haven't got that sort of money to spend on it, it's going to deteriorate... insurance is nearly a million pounds a year... and you've got to pay it". 
Many piers in this category are in need of repair, and some have had to close or demolish part of the pier deck because the structures require extensive maintenance and are not safe. In some cases, the high costs of upkeep and maintenance act as a constraint on innovation and the development of new products. This is especially evident at Southend Pier, where the extensive deck area results in significant maintenance costs:

"The pier loses, just on a revenue basis, $£ 380,000$ a year. The council subsidises it on a revenue basis then we spend millions on a capital basis. And I mean most of it you don't see it, it is replacing the steel edge, replacing the wood...".

Family Entertainment piers continue to offer relatively traditional products to the core market for British seaside resorts (families), whilst undertaking minor adaptations to ensure that they continue to cater for contemporary tastes and trends. This strategy of consolidation has been facilitated mainly by these piers' location in established, and continually popular, seaside resorts.

\section{Twenty-first Century Innovator piers}

Piers within this category are predominantly located in resorts with diverse economies less dependent on the tourism industry (such as Bournemouth and Aberystwyth), or resorts which are following a product diversification/regeneration strategy (such as Folkestone or Southwold). The majority of Twenty-first Century Innovator piers do not have protected status. Therefore, these piers face fewer restrictions on development, and most have undergone significant change since 2000 . This has resulted in $75 \%$ of Twenty-first Century Innovator piers having extensive indoor facilities and attractions, reducing open deck space. The majority of piers in this category are owned or operated within the commercial sector, with a strong commercial focus which underpins their product/market strategy. Like all piers they face ongoing maintenance costs.

Twenty-first Century Innovator piers have product and market development/diversification as their main strategic direction (Tribe 2016). Whilst they still feature traditional family entertainment products, they have been proactive in developing innovative products aligned with contemporary practices of consumption and entertainment. Some piers have focused on activity and adventure. For example, Skegness Pier has introduced an escape room and virtual reality experiences, while Clacton has introduced indoor adventure golf. Others (such as Felixstowe) have reconfigured themselves 
around high-end dining experiences, while Folkstone has developed contemporary bar, dining and socialising spaces intended for Millennial visitors.

Many commercial sector pier owners and operators stated that the vision and direction for their piers were based on their experience and expertise within specific attractions or sectors. Skegness Pier (owned and operated by a family with long-term experience of operating seaside attractions) indicated the importance of this expertise combined with knowledge of contemporary consumer trends:

"You can't just sit back and think, oh it is going to run itself; you need to continually be researching for new ideas to get people to come".

The strategy at Skegness is continual updating of the product offer in order to "get people talking and to get people in". The commercial operators of Bournemouth Pier developed an indoor climbing centre within the former pier theatre and the only pier-to-beach zip line. Such a radical diversification of the pier's product offering was based on the knowledge and experience of the CEO:

"I was an actor by trade ... the [pier] theatre was not working. I happen to have two passions in life which are live theatre and adventure sports...so I knew an awful lot about the way that industry was going...the very first clip and climb, I just happened to know about it before a lot of other people did".

The strategic direction of innovative piers is considered important not only to respond to external changes in demand, but also to differentiate themselves in a competitive environment (Tribe 2016). However, this approach involves higher risk, as not all new developments succeed. For example, the redevelopment of Penarth Pier Pavilion into a multipurpose events venue has been under-utilised by visitors and the local community, resulting in reduced operating hours. Many of the owners and operators of Twenty-first Century Innovator piers have similar resources to those operating Family Entertainment piers, but seemed more willing to take risks with the vision and direction of their piers:

"We took a lot of risks...we saw the potential...and we knew we could make a difference very quickly and we did, and that's why we're still here, so a lot of selfbelief I think" (Clacton). 
Risk-taking, especially amongst SMEs, is often associated with innovation (Massa and Testa 2008). Furthermore, Bullen and Love (2011) found that innovative adaptive reuse of heritage buildings enhance the long-term sustainability of these structures. Nevertheless, the risks associated with innovative adaptive reuse are even higher when organisations diversify into new markets with new products (such as at Penarth). The risk inherent in this approach may explain why this group of piers is the smallest of the three categories.

The type and variety of products offered at innovator piers reflects a broader target market, including 'pre-nesters' (aged 16-34 years without children) and 'independents' (aged 35-54 without children), which account for $11 \%$ and $14 \%$ of all coastal visitors (NCTA 2016). This approach broadens the piers' scope, and can be considered a form of related diversification (Whittington et al 2020), reducing the risk associated with diversification strategies (Evans 2015).

Some piers in this category have developed products catering for the local community, rather than traditional visitor markets. For example, Herne Bay features a 'Pier Village' - a range of small retail units offering specialist and boutique leisure shopping. This is considered a "low risk, low cost" option as it required minimal investment. Similarly, Boscombe Pier developed an interactive musical trail as part of the resort's wider 'Coastal Activity Park' project. A growing number are also now licensed for weddings and operators observed that piers are popular settings for couples requiring an unusual wedding venue.

Instead of focusing solely on the family market, innovative pier operators aim to make the pier an "overall destination" (Bournemouth), providing a variety of experiences to meet differing visitor needs (McKercher and Koh 2017). The extended product and market mix adopted by innovative pier owners is evident at Clacton Pier:

"You've got to sort of stick to your traditional values but also be current, and I think in today's world... they kind of go hand-in-hand don't they? People want a traditional British [offering] but they want it in a quirky surrounding, and it actually feels quite modern to the millennials and people like that".

The product diversification and adaptive reuse of Twenty-first Century Innovator piers may also minimise seasonal fluctuations in demand. Whilst Family Entertainment piers accept seasonality, operators of Twenty-first Century Innovator piers attempt to extend the season by adopting a product 
extension and development strategy (Goulding 2008). Underpinning this strategy is the development of a year-round product to avoid the need for winter closure. The owner of Felixstowe Pier stated:

"You have got to try and make piers viable and 52 weeks of the year is the only way to do it. So you have got to have mainly indoor attractions really... it is paramount trying to foster a 52 week a year operation now with any pier".

Many of these piers also run an events programme throughout the year, including Easter, Christmas and Halloween. Twenty-first Century Innovator piers can provide a product portfolio which appeals to a number of different markets, therefore reducing their risk and vulnerability to seasonal variations in demand (Benur and Bramwell, 2015).

\section{The Heritage pier}

The emergence of the Heritage pier can be considered in the context of recent changes in the nature of heritage tourism in the UK. Over the past decade there has been an increased interest and appreciation of the distinctive architectural heritage of the seaside (Brodie, 2018; Jarratt and Gammon, 2016), especially among statutory agencies. At the same time there is growing nostalgia for the intangible heritage of the seaside holiday itself (Chapman and Light 2011; Jarratt and Gammon 2016), a nostalgia which also extends to local communities (Brydon et al 2019). These broader developments create opportunities for seaside towns to promote themselves as destinations for heritage tourism, a trend termed the 'blue-grey transition' (Ashworth 2010: 287). The heritagisation strategy adopted by some piers is one component of this transition.

Approximately $50 \%$ of Heritage piers are located in smaller seaside towns (defined as those settlements with a permanent population below 10,000 people (Beatty et al 2011)). Such settlements are often characterised by a small, but significantly older population ( $34 \%$ are over retirement age), and lower ethnic minority and migrant populations (ibid). They tend to be in more remote locations such as Beaumaris, Cromer, and Saltburn. Other Heritage piers are located in larger seaside resorts with traditional, and often aging, tourism markets such as Torquay, Great Yarmouth, and Blackpool, but are often the second pier in the locale. $58 \%$ of Heritage piers are listed buildings and this status restricts development by placing limitations on the provision of any new buildings or attractions which would affect the pier's overall appearance. 
Heritage piers offer a different product from those in the other two categories. Due to their listed status they have retained many original design features, characterised by open decks and relatively small pavilions or entrance buildings. As such their product is focused around quiet relaxation and contemplation, and opportunities for promenading. Most Heritage piers (69\%) still serve their original purpose as a transport hub for pleasure and passenger ships, and maintain their landing facilities. Several piers have conserved their existing buildings, including theatres, tea rooms and sun lounges. Of the remaining five pier theatres, four are to be found on Heritage piers. Heritage piers show some extension of scope, with minor product development undertaken, such as high-quality food and beverage and discrete boutique retail. Many have added on-pier interpretive panels or offer guided tours for visitors, and a few have also added visitor centres which interpret the pier's history (e.g. Clevedon, Harwich and Swanage).

The main target market for Heritage piers are 'empty nesters' (55+, no dependant children), who account for $33 \%$ of domestic visitors to the seaside (NCTA 2016). This is an example of market development, where existing products are packaged for new markets (Whittington et al, 2020). The empty nester market tends to visit the seaside outside of peak season (NCTA 2016) and therefore piers in this category are less susceptible to seasonal demand. Off-peak visits to Swanage Pier by this market are evident:

"If everything (on the pier) was closed, and no attractions were open, the one consistent market that would constantly go back are the 50-plus year olds that go because they appreciate heritage, they appreciate scenery and the quiet enjoyment".

Heritage piers benefit from a growing nostalgia in the UK for the traditional seaside holiday (Jarratt and Gammon, 2016). Older visitors have historically shown a high level of engagement with heritage tourism in the UK (Garrod and Fyall 2000). They also target local residents, especially families. Accordingly, Heritage piers seek to provide experiences that match the requirements of these groups:

“It's not glitzy, millions and millions of people like Blackpool is, it's not like those places and we don't want it to be. So, I think it fits really well with the slightly gentler, less inyour-face tourism, it's definitely family, it's definitely older people" (Cromer Pier).

Most Heritage piers (89\%) are owned or operated by public sector bodies $(68 \%)$ or charitable trusts (21\%). The two commercially owned and operated piers within this category are at Great Yarmouth 
and Blackpool, where both resorts offer additional piers, so the Heritage piers can be considered as a product and market differentiation strategy to nearby competitor piers. The owner of both piers at Great Yarmouth also owns Felixstowe Pier, therefore operating piers in all three categories. He argued that differentiation is key:

\begin{abstract}
"We have targeted different markets, it's not by accident, it's by design, because there is no point in them being in total competition to each other. So we try keep [Great Yarmouth] Britannia Pier more a candy floss style operation, the old traditional pier that you would see, the old sort of postcard type operation really, which it still has its following and certainly with the theatre and all the things you would expect, old traditional fish \& chips and so forth" (Great Yarmouth Britannia/Felixstowe).
\end{abstract}

Nevertheless, the majority of owners in this category renounce overtly commercial attractions preferring to focus on their structure's historical and architectural importance. $82 \%$ of Heritage piers owned by public or third sector organisations have received funding for conservation and restoration over the last decade, with a significant proportion of these funds provided through the Coastal Communities Fund and the Heritage Lottery Fund. Whilst access to public funding schemes has inevitably benefitted Heritage piers, such funding does have some restrictions attached. For example, the Heritage Lottery Fund has a mandatory outcome that 'a wider range of people will be involved in heritage' for any funding applications. These outcomes may hinder potential innovative use or development of some Heritage piers, with this limitation noted by the commercial operator of Bournemouth Pier:

\begin{abstract}
"One of our biggest problems in coastal resorts is that the planning system looks at preserving the architectural past, not the purpose of the structure...it's always celebration of the architect that designed it. So, I think we need an organisation that goes 'well what was the purpose of this space, how do we preserve that purpose into the future and if there is no future for that purpose then is there a new purpose'?"
\end{abstract}

Similarly, the public sector owner of Cromer Pier highlights:

\footnotetext{
"Because of its heritage value...I think there are some limiting factors on function and facilities, infrastructure on the pier, because you can't build very much within its design....we have spent a lot of money on capital works in the last 12 months...there's a
} 
massive investment there and that is without the general day-to-day maintenance of the pier, which is about $£ 250,000$ a year...it is never ending and we will never stop because of what it is and where it is".

Whilst the heritage value of these structures cannot be doubted, relatively few Heritage piers are financially self-sustaining and are therefore dependent on public sector investment or other sources of external funding. This places them in a precarious position if such funding is no longer available.

\section{Conclusion}

Heritage structures, by their very nature, must adapt to changing circumstances. This frequently takes the form of adaptive reuse, that is configuring a structure for contemporary use as a visitor attraction. However, in this paper we have considered a different form of adaptation by focusing on heritage structures - seaside piers - that were always intended to be visited by tourists. The challenges of adaptation involve responding to a dynamic and competitive external environment over which piers can have little influence. In particular, piers need to adapt to changing patterns of demand among visitors so that they remain relevant and attractive for contemporary tourists.

In this paper we have identified ways in which seaside piers have responded and adapted to changes in demand. The first is an emphasis on a product traditionally associated with the seaside holiday and centred on family entertainment. This has been adopted by piers in predominantly private-sector ownership and which is underpinned by consolidating the traditional product whilst diversifying (through enhanced catering and events) to cater for changing expectations of their visitors. The second approach involves more radical innovation and a move towards a more overtly Twenty-first century product based on contemporary entertainments, high-end catering, and in some cases an orientation towards the needs of local communities. This involves both product and market diversification and therefore can be the riskiest strategy to follow. The third strategy is one of heritagisation which seeks differentiation by asserting the heritage values of the seaside pier. This strategy involves catering for the needs of older visitor groups and is underpinned by nostalgia for the traditional seaside holiday.

These findings have broader relevance for other types of heritage resource by illustrating how it is possible to adapt to changes in demand and remain viable and competitive as visitor attractions. Piers illustrate how identifying changing consumer tastes and catering for contemporary needs is essential. 
They also illustrate how strategies of consolidation of an existing product, or differentiation to distinguish themselves from other types of attraction enable piers to claim a distinctive position in a contemporary visitor economy. Like other heritage resources, seaside piers face the ongoing challenge of maintenance costs. However, they also confront specific challenges in the former of catastrophic events such as fire or storm damage which can require substantial funding to address. They also face the longer-term implications of rising sea levels. Only those piers that are most commercially orientated are able to generate sufficient surpluses to fund maintenance. In other cases they are dependent on external funding (whether local authority support or grants from charities) which may not be available, particularly in the aftermath of a catastrophic event. Therefore, like other heritage resources, some piers are in a precarious position with regard to their longer-term financial sustainability and viability.

Funding: This work was funded by the Coastal Revival Fund (UK Ministry of Housing, Communities and Local Government)

\section{References}

Adamson, S.H. (1977). Seaside piers. London: Batsford

Ashworth, G.J. (2010). Consuming heritage places: Revisiting established assumptions. Tourism Recreation Research, 35(3),281-290.

Attractions Management (2016). Attractions Foresight 2016. Attractions Management, 21 (1),44-51.

Bąkiewicz, J., Leask, A., Barron, P. and Rakić, T. (2017). Management challenges at film-induced heritage attractions. Tourism Planning and Development, 14(4),548-566.

Beatty, C., Fothergill, S. and Wilson, I. (2011). England's smaller seaside towns: A benchmarking study. London: Department for Communities and Local Government

Benur, A.M. and Bramwell, B. (2015). Tourism product development and product diversification in destinations. Tourism Management, 50,213-224. 
Braun, V. and Clarke, V. (2006). Using thematic analysis in psychology. Qualitative Research in Psychology, 3(2),77-101.

Brodie, A. (2018). The seafront. Swindon: Historic England.

Brydon, L., Jenzen, O. and Nourse, N. (2019). 'Our pier': Leisure activities and local communities at the British seaside. Leisure, 43(2),205-228.

Bryman, A. (2016). Social research methods (5 $5^{\text {th }}$ edition). Oxford: Oxford University Press

Bullen, P.A. and Love, P.E.D. (2011). Adaptive reuse of heritage buildings. Structural Survey, 29(5), 411-421.

Chapman, A. and Light, D. (2011). The 'heritagisation' of the British seaside resort: The rise of the 'old penny arcade'. Journal of Heritage Tourism 6 (3),209-226.

Chapman, A., Richards, S. and Blake, A. 2020. Pier Review: Sustainability Toolkit for British Seaside Piers. https://piers.org.uk/news/national-piers-society-releases-major-new-study-on-britishseaside-piers/Accessed $17^{\text {th }}$ July 2020

Chhabra, D. (2007). Exploring market influences on curator perceptions of authenticity. Journal of Heritage Tourism, 2(2),110-119.

Chan, W., Zhang, C.X., Hon, A. and Mak, B. (2015). New business drivers of Hong Kong cultural museums: The tourism stakeholder perspective. Asia Pacific Journal of Tourism Research, 20(6),619634.

Connell, J., Page, S.J., and Meyer, D. (2015). Visitor attractions and events: Responding to seasonality. Tourism Management. 46,283-298.

Darlow, S., Essex, S. and Brayshay, M. (2012). Sustainable heritage management practices at visited heritage sites in Devon and Cornwall. Journal of Heritage Tourism, 7(3),219-237.

Evans, N. (2015). Strategic management for tourism, hospitality and events. Oxford: Routledge. 
Flick, U. (2018). An introduction to qualitative research. London: Sage.

Garrod, B. and Fyall, A. (2000). Managing heritage tourism. Annals of Tourism Research, 27(5),682708.

Goulding, P. (2008) Managing temporal variation in visitor attractions. In A. Fyall, B. Garrod, A. Leask \& S. Wanhill (Eds). Managing visitor attractions. (pp.197-216). Oxford: Butterworth-Heinemann

Hall, C.M., Baird, T., James, M. and Ran, Y. (2016). Climate change and cultural heritage: conservation and heritage tourism in the Anthropocene. Journal of Heritage Tourism, 11(1),10-24.

Helfat, C.E., S. Finkelstein, W. Mitchell, M. Peteraf, H. Singh, D.J. Teece, and Winter S.G., (2007). Dynamic capabilities: Understanding strategic change in organisations. Oxford: Blackwell.

Ho, P.S.Y and McKercher, B. (2004). Managing heritage resources as tourism products. Asia Pacific Journal of Tourism Research, 9(3),255-266.

Hughes, M. and Carlsen, J. (2010). The business of cultural heritage tourism: Critical success factors. Journal of Heritage Tourism, 5(1),17-32.

Jarratt, D. and Gammon, S. (2016). 'We had the most wonderful times': seaside nostalgia at a British resort, Tourism Recreation Research, 41 (2),123-133.

Jovicic, D. (2016). Cultural tourism in the context of relations between mass and alternative tourism. Current Issues in Tourism, 16(6),605-612.

Kearns, R.A. (2005). Knowing seeing? Undertaking observational research. In I. Hay (Ed.), Qualitative research methods in human geography (second edition) (pp. 192-206). Oxford: Oxford University Press.

Kluge, S. (2000). Empirically Grounded Construction of Types and Typologies in Qualitative Social Research. Forum: Qualitative Social Research, 1 (1), Art.14. 
Leask, A. (2016). Visitor attraction management: A critical review of research 2009-2014. Tourism Management, 57,334-361.

Markwell, S., Bennett, M. and Ravenscroft, N. (1997). The changing market for heritage tourism: A case study of visits to historic houses in England. International Journal of Heritage Studies, 3(2),95108.

Massa, S., and Testa, S. (2008). Innovation and SMEs: Misaligned perspectives and goals among entrepreneurs, academics, and policy makers. Technovation, 28(7),393-407.

McKercher, B., Ho, P.S.Y. and du Cros, H. (2004). Attributes of popular cultural attractions in Hong Kong. Annals of Tourism Research, 31(2),393-407.

McKercher, B and Koh, E. (2017) Do attractions "attract" tourists? The case of Singapore. International Journal of Tourism Research,19(6),661-671.

McGuinness, M., and Johnson, N., (2014). Exploiting Social Capital and Path-dependent Resources for Organisational Resilience: Preliminary Findings from a Study on Flooding. Procedia Economics and Finance, 18,447-445.

Miller, G., Hudson, S. and Turner, R. (2005). Applying the mystery shopping technique: The case of Lunn Poly. In B.R Ritchie, P. Burns, and C. Palmer (Eds.), Tourism research methods: Integrating theory with practice (pp.119-130). Wallingford: CABI

NCTA (National Coastal Tourism Academy) (2016). 2016 Coastal Tourism.

https://coastaltourismacademy.co.uk/resource-hub/resource/2016-coastal-tourism Accessed $01 / 03 / 2020$

NLHF (National Lottery Heritage Fund) (2019). 25 years of National Lottery love for the UK's great outdoors. Available from https://www.heritagefund.org.uk/news/25-years-national-lottery-love-uksgreat-outdoors Accessed on 01/03/20 
Richards, S. and Wilkes, K. (2008). Attraction failure and success. In A. Fyall, B. Garrod, A. Leask \& S. Wanhill (Eds.), Managing visitor attractions (second edition) (pp.39-58). Oxford: ButterworthHeinemann.

Stevens, T. (2000). The future of visitor attractions. Travel and Tourism Analyst, (1),61-85.

Timothy, D.J. and Boyd, S.W. (2003). Heritage tourism. Harlow: Pearson.

Timothy, D. and Boyd, S. (2006). Heritage tourism in the Twenty-first century: Valued traditions and new perspectives. Journal of Heritage Tourism, 1(1),1-16.

Tribe, J. (2016). Strategy for tourism. Oxford: Goodfellow Publishers.

VisitBritain (2019a). Annual survey of visits to visitor attractions 2018.

https://www.visitbritain.org/annual-survey-visits-visitor-attractions-latest-results Accessed 01/03/20.

VisitBritain (2019b). Most visited free attractions 2018.

https://www.visitbritain.org/sites/default/files/vb-corporate/most visited free 2018.pdf Accessed 01/03/2020.

Walton, J.K. (1992). Wonderlands by the waves. Lancashire: County Books

Weber, M., Groulx, M., Lemiuex, C.J., Scott, D. and Dawson, J. (2019). Balancing the dual mandate of conservation and visitor use at a Canadian world heritage site in an era of rapid climate change. Journal of Sustainable Tourism, 27(9),1318-1337.

Weidenfeld, A., Butler, R. and Williams, A.M. (2016). Visitor attractions and events: Locations and linkages. Abingdon: Routledge.

Whittington, R., Regner, P., Angwin, D., Johnson, G., and Scholes K. (2020) Exploring strategy. Harlow: Pearson.

Wills, A. and Phillips, T. (2014) British seaside piers. Swindon: English Heritage. 